\title{
Synthesis and Characterization of Polymers Bearing Thiourea Moiety and Study Their Efficiency in Removing Heavy Metal Ions from Aqueous Solutions
}

\author{
Hamed Jasim Jaffer* and Hawra`a Sarhan Reshan \\ Department of Chemistry, University of Mustansiria, Baghdad-Iraq. \\ * Corresponding author: hamedjaffer3@yahoo.com
}

\begin{abstract}
Two new polymers were synthesized poly[5-amino-1,3,4-thiadiazol-2-yl (6-methanethioamido-6-oxohexanoyl)carbamodithioate $]$ and Poly[ $\mathrm{N}^{1}-\left((6\right.$-aminopyridin-2-yl $)$ carbamothioyl)- $\mathrm{N}^{6}$ thioformyladipamide]. These polymers were characterized by FTIR, ${ }^{1} \mathrm{H}$ and ${ }^{13} \mathrm{C}$ NMR spectra. These polymers were tested in removing some heavy metal ions ( $\mathrm{Cu}(\mathrm{II}), \mathrm{Cd}(\mathrm{II}), \mathrm{Zn}(\mathrm{II})$, and $\mathrm{Co}(\mathrm{II})$ ) from water. The adsorption behavior of these polymers has been studied using different parameters such as, contact time, initial metal ion concentration, weight of the polymer, $\mathrm{pH}$ of the solution and temperature. This study reveals that the two polymers have high adsorption capacity for mentioning metal ions. Langmuir, and Freundlich isotherm models were used to fit the experimental data. The experimental data of the adsorption equilibrium correlates well with the isotherm equations.

[DOI: 10.22401/JNUS.21.3.05]
\end{abstract}

Keywords: Thiourea, Adipoyl dichloride, Heavy metal, Adsorption capacity, Thermodynaminc parameters.

\section{Introduction}

Thiourea compounds occupy an important position between organic compounds as potential donor ligands especially for transition metal ions [1-6]. This ability is originated from their carbonyl and thiocarbonyl groups [7]. Moreover, they have a large tendency for the formation of hydrogen bonding [8]. Their derivatives have a wide range of applications, such as potential therapeutic agents [9], in agrochemical materials [10], anti-corrosion inhibitors [11], and other important uses [12,13]. They are often synthesized by alkyl, aryl, and aroyl isothiocyanates [14]. Phenylthiourea was prepared from the reaction of benzoylisothiocyanate with aniline [15]. NMono and N,N-disubstituted thioureas obtained by condensation of silicon tetraisothiocyanate with primary amines in excellent yields [16]. Additionally, the bifunctional thiourea, 1,4phenylenebisthiourea, was prepared directly from 1,4-phenylenediamine and two moles of ammonium thiocyanate under acidic condition. Moreover, a significant thiourea compounds were preapered by the nucleophilic addition reaction of potassium thiocyante to cyclohexanecarbonyl chloride and the resulted intermediate was treated in situ with various secondary amines [17]. 1-Benzoyl-3propylthiourea was prepared by analogue method and proved to be efficient in removing mercuray ion from aqueous solution [18]. Some polymers bearing thiourea moiety were synthesized by the aid of solid-liquid phase transfer catalysis. A method for preparation of arene-bisaroyl(thioureas) was reported using poly (ethylene glycol) 600 (PEG-600) as a phase transfer catalyst [19]. Novel acylthiourea polymers containing aryl ring and thiourea groups were prepared by a convenient and efficient method using of solid-liquid phase transfer catalyst, poly (ethylene glycol) 400 (PEG-400) [20].

In this work, we have planned to synthesize polymers bearing multifunctional groups in the backbone of its structure. This design could be carried out without using catalyst through the reaction of adipoylisothiocyanate with compounds have two active functional groups, 5-amino-1,3,4thiadiazole-2-thione or 2,6-diaminopyridine. Moreover, the work is targeted to examine the ability of the resulted polymers to function as efficient adsorbents in removing some heavy metal ions from aqueous solutions under various conditions. 


\section{Experimental Work}

\subsection{Instrumentation}

Melting points were determined on Electro-thermal capillary apparatus (stuart) and are uncorrected; FT-IR measurements were recorded on Shimadzu model FTIR8400S. ${ }^{1} \mathrm{H}$ NMR and ${ }^{13} \mathrm{C}$ NMR spectra were obtained with Bruker spectrometer model ultra-shield at $300 \mathrm{MHz}$ and $100 \mathrm{MHz}$ respectively. The results were recorded using tetramethylsilane (TMS) as internal standard and DMSO- $\mathrm{d}_{6}$ as solvent. Chemical shifts are given in $\delta$ scale (ppm). Atomic absorption data were obtained with the aid of a Phoenix-986 AA spectrophotometer. Note: in some ${ }^{1} \mathrm{H}$ NMR spectra, the peaks at chemical shifts 2.5 and 3.35 are for the solvent $\left(\mathrm{DMSO}-\mathrm{d}_{6}\right)$ and dissolved water in $\left(\right.$ DMSO- $\left._{6}\right)$, respectively.

\subsection{Synthesis of polymers}

All the chemicals used in this work were purchased from sigma- Aldrich and used it is without further purification.

A solution of adipoyl dichloride $(10 \mathrm{mmol}$, $1.83 \mathrm{~g})$ in acetone $(25 \mathrm{~mL})$ was added dropwise to a cooled solution of ammonium thiocyanate $(20 \mathrm{mmol}, 1.52 \mathrm{~g})$ in acetone $(50 \mathrm{~mL})$ at $\left(0-5^{\circ} \mathrm{C}\right)$ during 30 minutes and the reactants were stirred for $2 \mathrm{hrs}$, the formed precipitate was removed by filtration. The filtrate was treated with 5-amino-1,3,4thiadiazole-2-thione $(10 \mathrm{mmol}, 1.33 \mathrm{~g})$ to synthesize polymer $\mathrm{P}_{1}$ and with 2,6diaminopyridine (10 mmol, $1.09 \mathrm{gm})$ to synthesize polymer $\mathrm{P}_{2}$ in acetone $(50 \mathrm{~mL})$. The addition was dropwise with continuous stirring at room temperature. The reaction mixture was left stirring overnight, during which a polymeric precipitate was formed. The product was separated by filtration and washed with hot acetone [17].

\section{Poly[5-amino-1,3,4-thiadiazol-2-yl(6- methanethioamido-6-oxohexanoyl) carbamodithioate] $\left(\mathbf{P}_{1}\right)$}

Yield $74 \%$, MP $=258-270^{\circ} \mathrm{C}$. FT-IR $\left(\mathrm{cm}^{1}\right): 3132(\mathrm{~N}-\mathrm{H}), 2983,2893$ (C-H aliph.), $1654(\mathrm{C}=\mathrm{O}), 1577(\mathrm{C}=\mathrm{N}), 1064(\mathrm{C}=\mathrm{S})$.

${ }^{1} \mathrm{H}$ NMR (DMSO-d $\mathrm{d}_{6},(\delta \mathrm{ppm}) 1.22-2.22$ $\left(8 \mathrm{H}, \mathrm{m}, \mathrm{CH}_{2}\right), 12.5\left(2 \mathrm{H}, \mathrm{s} \mathrm{N}-\mathrm{H}_{\mathrm{A}}\right), 14.0(1 \mathrm{H}, \mathrm{s}$, $\left.\mathrm{N}-\mathrm{H}_{\mathrm{B}}\right)$.

${ }^{3} \mathrm{C}$ NMR $\left(\delta\right.$ ppm) $23.70-34.31\left(\mathrm{CH}_{2}\right)$, $152.12(\mathrm{~S}-\mathrm{C}=\mathrm{Nc}), 172.02\left(\mathrm{~N}-\mathrm{C}=\mathrm{N}_{\mathrm{d}}\right), 172.10$ $(\mathrm{C}=\mathrm{O}), 183.48(\mathrm{C}=\mathrm{S})$.
Poly[ $\mathrm{N}^{1}$-((6-aminopyridin-2-yl) carbamothioyl)- $\mathbf{N}^{6}$-hioformyladipamide] $\left(\mathbf{P}_{2}\right)$

Yield $76 \%$, MP $=200-207^{\circ} \mathrm{C}$, FT-IR $\left(\mathrm{cm}^{-1}\right): 3180(\mathrm{~N}-\mathrm{H}), 2980,2858$ (C-H aliph.), $1689(\mathrm{C}=\mathrm{O}$ amide $), 1572(\mathrm{C}=\mathrm{N}), 1147(\mathrm{C}=\mathrm{S})$.

${ }^{1} \mathrm{H}$ NMR (DMSO-d $6,(\delta \mathrm{ppm}) 1.50-2.15$ $\left(8 \mathrm{H}, \mathrm{m}, \mathrm{CH}_{2}\right), 11.7\left(2 \mathrm{H}, \mathrm{s}, \mathrm{N}-\mathrm{H}_{\mathrm{a}}\right), 13.1(2 \mathrm{H}, \mathrm{s}$, $\left.\mathrm{N}-\mathrm{H}_{\mathrm{b}}\right), 8.65\left(2 \mathrm{H}_{\mathrm{c}}, 2 \mathrm{~d}\right)$ and $7.96\left(\mathrm{~m}, 1 \mathrm{H}_{\mathrm{d}} \mathrm{m}\right)$ protons of pyridine ring.

${ }^{13} \mathrm{C}$ NMR $(\delta \mathrm{ppm})$ 23.61-35.62 $\left(\mathrm{CH}_{2}\right)$, 112.73-152.92 (Five carbons of the pyridine ring), $177.73(\mathrm{C}=\mathrm{O}), 191.14(\mathrm{C}=\mathrm{S})$.

\subsection{Heavy metal removal experiments}

For removal studies of metal ions (Cu(II), $\mathrm{Cd}(\mathrm{II}), \mathrm{Zn}(\mathrm{II})$, and $\mathrm{Co}(\mathrm{II})$ ) by the synthesized polymers, a solutions of $(2 \mathrm{mg} / \mathrm{L})$ of these ions in deionized water was prepared using $\mathrm{Cu}\left(\mathrm{NO}_{3}\right)_{2}, \mathrm{Cd}\left(\mathrm{NO}_{3}\right)_{2}, \mathrm{Zn}\left(\mathrm{NO}_{3}\right)_{2}$ and $\mathrm{Co}\left(\mathrm{NO}_{3}\right)_{2}$ salts and regarded as a synthetic polluted solutions. $(50 \mathrm{mg})$ of polymer $\mathrm{P}_{1}$ or $\mathrm{P}_{2}$ was suspended in a $(10 \mathrm{~mL})$ of metal ion solution $(2 \mathrm{mg} / \mathrm{L})$ in a $(10 \mathrm{~mL})$ volumetric flask. The suspended solution was stirred for $1,3,5,10,20,30$, and 180 minutes at $25^{\circ} \mathrm{C}$. The polymer sample was removed by filtration and the metal ion concentration in the filtrate was determined by flame atomic absorption spectrometry.

\section{Results and Discussion}

\subsection{Synthesis}

The new polymers in this research were synthesized in a good yield $(74-76 \%)$ by reaction of adipoyl dichloride with ammonium thiocyanate in acetone at low temperature $\left(0-5^{\circ} \mathrm{C}\right)$, in a $1: 2$ mole ratio. The precipitated salt $\left(\mathrm{NH}_{4} \mathrm{Cl}\right)$ was separated by filtration and the filtrate (solution of adipoylisothiocyanate (I) in acetone) was treated with 5-amino-1,3,4 thiadiazole-2-thione or 2,6-Diaminopyridine in a 1:1 mole ratio at room temperature with continuously stirring for $24 \mathrm{hrs}$. The first step of the reaction proceeds via nucleophilic substitution mechanism which led to formation of intermediate (I)[21]. Moreover, the polymer formation $\left(\mathrm{P}_{1}\right.$ and $\left.\mathrm{P}_{2}\right)$ produced by a step polymerization mechanism [22] by the reaction of the intermediate (I) with nucleophil possess two active functional groups. Scheme (1) clarifies the reaction steps and the 
conditions used for the synthesis of polymers $\mathrm{P}_{1}$ and $\mathrm{P}_{2}$.

\subsection{IR and NMR spectra}

The FT - IR spectrum of polymer $\left(\mathrm{P}_{1}\right)$, exhibited two bands at the usual position of $\mathrm{C}-\mathrm{H}$ aliphatic stretching vibration (asymmetric and symmetric) $2983 \mathrm{~cm}^{-1}$ and $2893 \mathrm{~cm}^{-1}$. of $\mathrm{CH}_{2}$ group. The spectrum also showed characteristic bands at $3132 \mathrm{~cm}^{-1}, 1654 \mathrm{~cm}^{-1}$, $1577 \mathrm{~cm}$ and $1064 \mathrm{~cm}^{-1}$ could be assigned for stretching vibration of $\mathrm{N}-\mathrm{H}, \mathrm{C}=\mathrm{O}$ (amide), $\mathrm{C}=\mathrm{N}$, and $\mathrm{C}=\mathrm{S}$ groups respectively [21-23]. The spectrum showed the disappearances of stretching vibration of adipoyl carbonyl $(\mathrm{C}=\mathrm{O})$ which usually appeared at high frequency $1790 \mathrm{~cm}^{-1}$.

The ${ }^{1} \mathrm{H}$ NMR spectrum of $\mathrm{P}_{1}$ polymer in DMSO $d_{6}$, Fig.(1), showed a multiplet signal between $(\delta=1.22-2.22 \mathrm{ppm})$, assigned to eight protons of the aliphatic chain $\left(\mathrm{CH}_{2}\right)_{4}$. The spectrum also exhibited two singlet signals at $(\delta=12.50 \mathrm{ppm}, 2 \mathrm{H})$ and $(\delta=14.0 \mathrm{ppm}, 1 \mathrm{H})$, the first signal could be attributed to the protons of $\left(\mathrm{N}-\mathrm{H}_{\mathrm{A}}\right)$, while the second signal is assigned for the proton attached to $\left(\mathrm{N}-\mathrm{H}_{\mathrm{B}}\right)$.
The two signals were disappeared from the spectrum after addition of $\mathrm{D}_{2} \mathrm{O}$ due to the proton exchange on $\mathrm{N}$ atoms, this exchange provides a profound support to the position of $\mathrm{N}-\mathrm{H}$ protons in the structure of the polymer. The ${ }^{13} \mathrm{C}$ NMR spectrum, Fig.(2), exhibited chemical shift at the range $(\delta=23.70-34.31$ $\mathrm{ppm})$, was assigned to the $\left(\mathrm{CH}_{2}\right)$ carbon atoms of the hydrocarbon chain. Moreover, the spectrum showed two signals at $(\delta=152.12$ $\mathrm{ppm})$ for the atom $\left(\mathrm{C}_{\mathrm{c}}\right)$ and at $(\delta=172.02$ $\mathrm{ppm})$, which is attributed to the carbons of $\left(\mathrm{C}_{\mathrm{d}}\right)$. The last two signals that appeared at $(\delta=172.10 \mathrm{ppm})$ and $(\delta=183.48 \mathrm{ppm})$ are related to the carbons of $(\mathrm{C}=\mathrm{O})$ and $(\mathrm{C}=\mathrm{S})$ respectively [21-23].

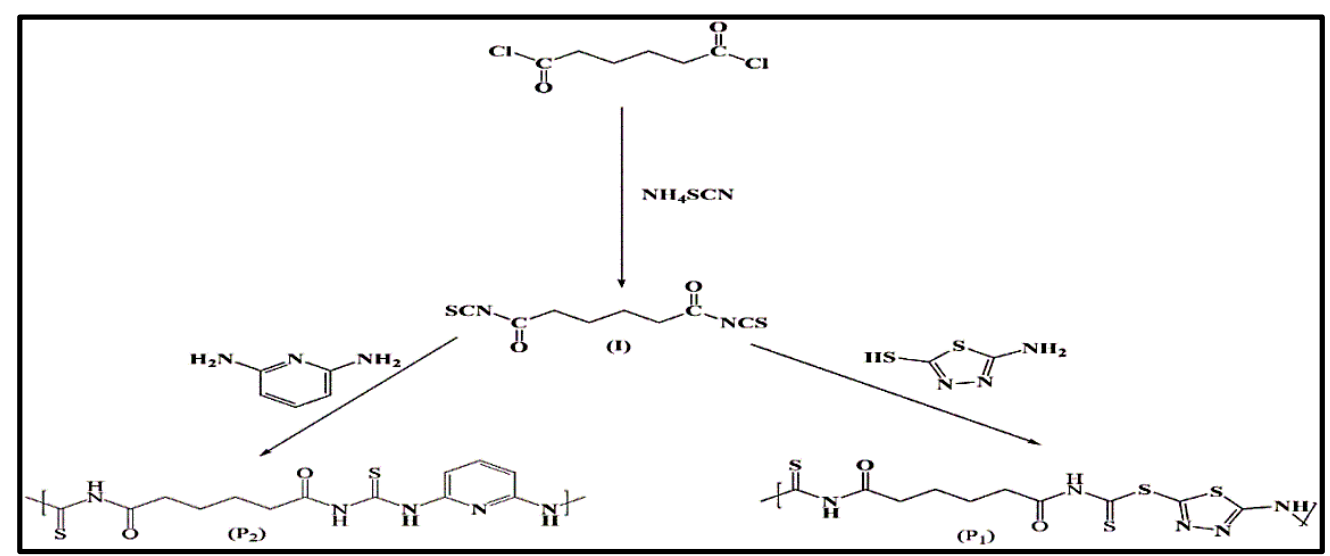

Scheme (1): General route for synthesis of polymers $\left(P_{1}\right.$ and $\left.P_{2}\right)$.

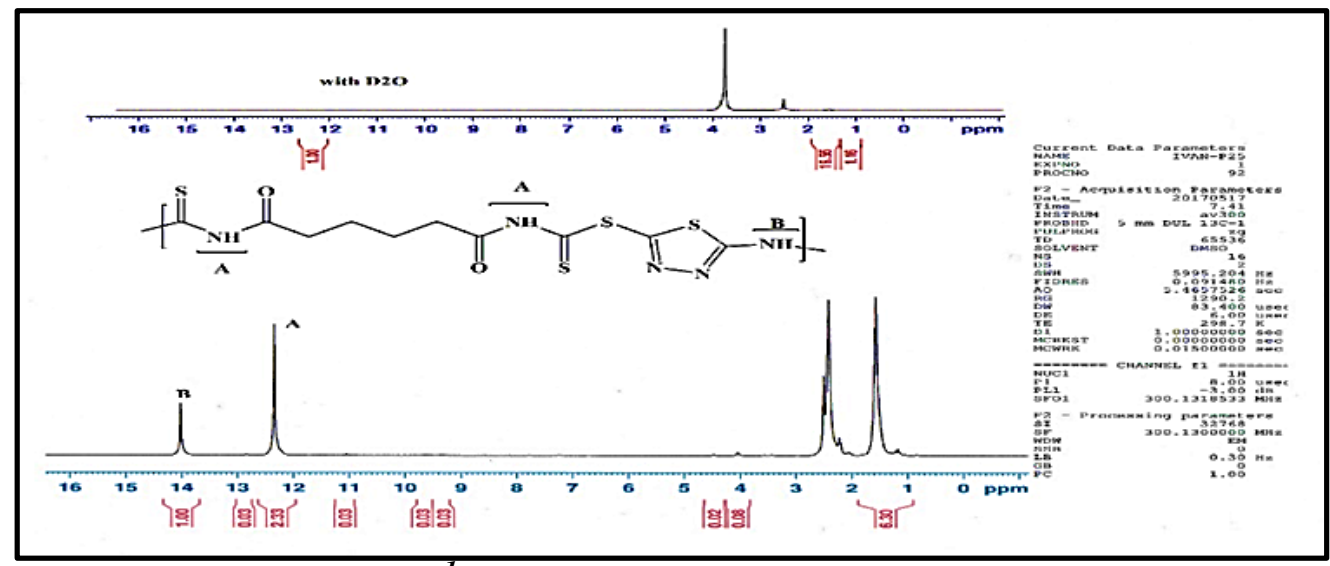

Fig.(1): ${ }^{I}$ HNMR Spectrum of polymer $\left(P_{1}\right)$. 


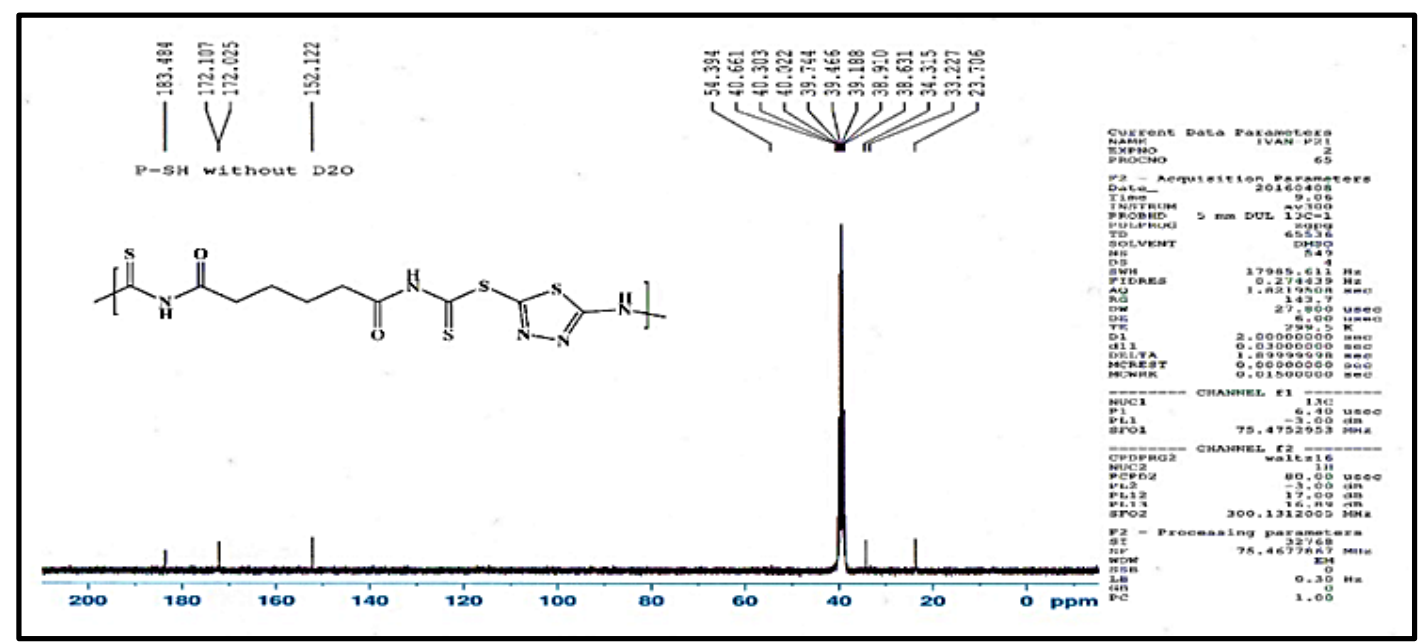

Fig.(2): ${ }^{13}$ C NMR Spectrum of polymer $\left(P_{1}\right)$.

The FT-IR spectrum of polymer $\left(\mathrm{P}_{2}\right)$, exhibited two bands belong to $\mathrm{C}-\mathrm{H}$ aliphatic stretching vibration (asymmetric and symmetric) $2980 \mathrm{~cm}^{-1}$ and $2858 \mathrm{~cm}^{-1}$. of $\mathrm{CH}_{2}$ group. The spectrum also showed characteristic bands at $3180 \mathrm{~cm}^{-1}, \mathrm{~N}-\mathrm{H}, 1689$ $\mathrm{cm}^{-1}, \mathrm{C}=\mathrm{O}$ (amide), 1572(C=N), and $1147 \mathrm{C}=\mathrm{S}$ $\mathrm{cm}^{-1}$. The spectrum showed the disappearances of stretching vibration of adipoyl carbonyl $(\mathrm{C}=\mathrm{O})$ which usually appeared at high frequency $1790 \mathrm{~cm}^{-1}$.

The ${ }^{1} \mathrm{H}$ NMR spectrum $\mathrm{P}_{2}$ in DMSO $\mathrm{d}_{6}$, figure (3) showed a multiplet signal between $(\delta=1.50-2.15 \mathrm{ppm})$, assigned to eight protons of aliphatic chain $\left(\mathrm{CH}_{2}\right)$. The spectrum also exhibited two singlet signals at $(\delta=13.10$ ppm, $2 \mathrm{H})$ and $(\delta=11.70 \mathrm{ppm}, 2 \mathrm{H})$, the first signal is due to the protons of $\left(\mathrm{N}-\mathrm{H}_{\mathrm{a}}\right)$, while the second signal is assigned for the protons attached to $\left(\mathrm{N}-\mathrm{H}_{\mathrm{b}}\right)$. The two signals were disappeared from the spectrum after addition of $\mathrm{D}_{2} \mathrm{O}$ due to the proton exchange on $\mathrm{N}$ atoms, giving a profound support to the position of $\mathrm{N}-\mathrm{H}$ protons in the spectrum of the polymer. The protons of the pyridine ring appeared as two doublet signals at $(\delta=8.65 \mathrm{ppm}),(2 \mathrm{~d} 2 \mathrm{H})$ and multiple signal at $(\delta=7.96 \mathrm{ppm}) \quad(\mathrm{m}, 1 \mathrm{H})$. The ${ }^{13} \mathrm{C} \mathrm{NMR}$ spectrum, Figure (4), exhibited at a signal at the range ( $\delta=23.61-35.62 \mathrm{ppm}$ ), was assigned to the $\left(\mathrm{CH}_{2}\right)_{4}$ carbon atoms of the hydrocarbon chain. The signals appeared in the range ( $\delta=112.73-152.92 \mathrm{ppm}$ ) are belong to the carbons of pyridine ring, while those signals appeared at $(\delta=177.73 \mathrm{ppm})$ and $(\delta=191.14 \mathrm{ppm})$ are related to the carbons of $(\mathrm{C}=\mathrm{O})$ and $(\mathrm{C}=\mathrm{S})$ respectively.

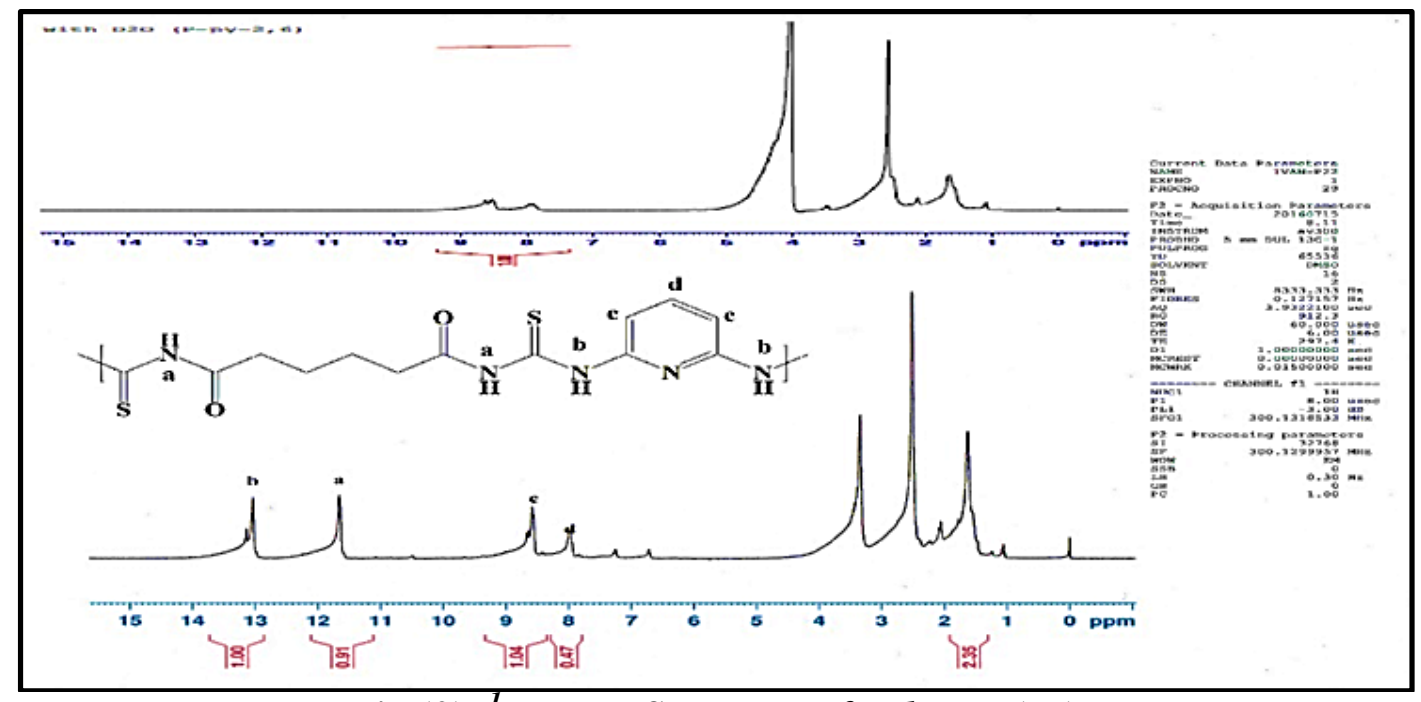

Fig.(3): ${ }^{1}$ HNMR Spectrum of polymer $\left(P_{2}\right)$. 


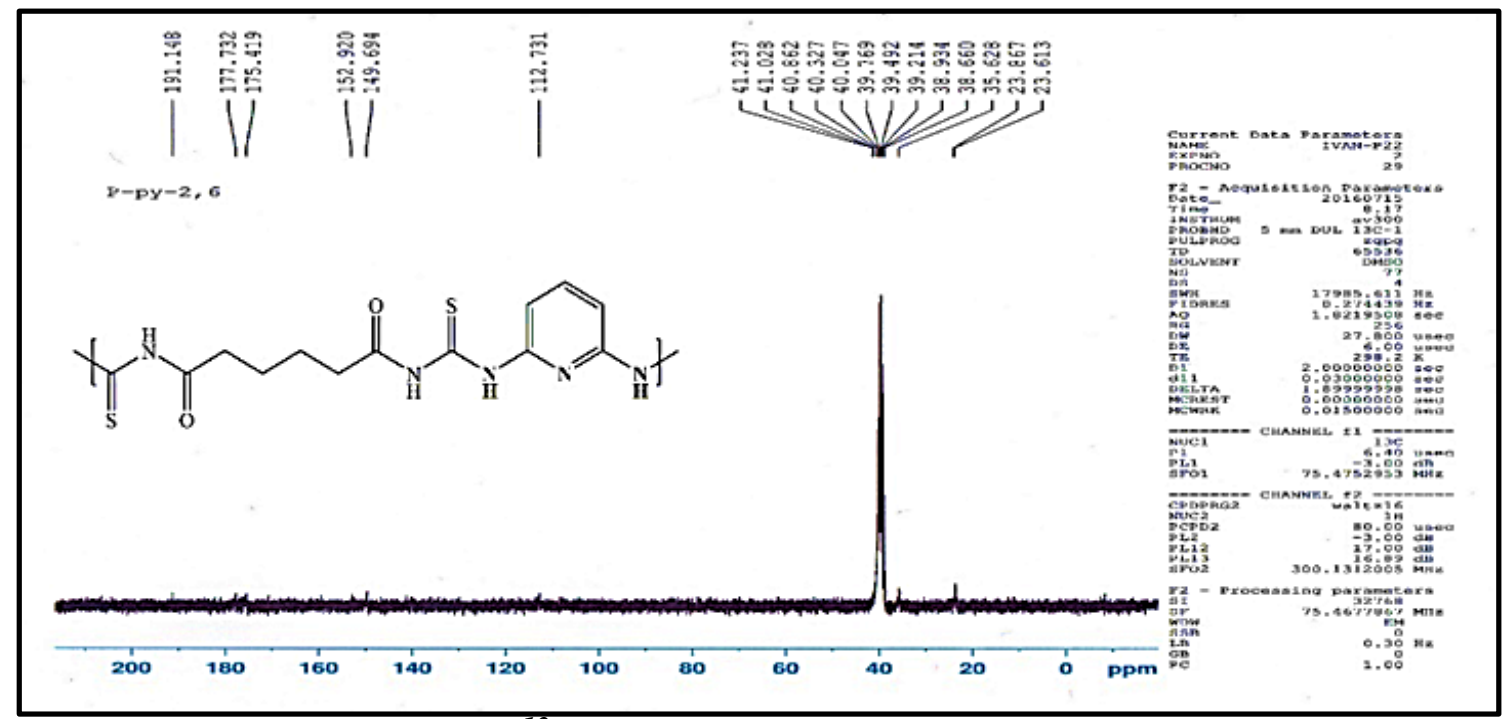

Fig.(4): ${ }^{13} \mathrm{C}$ NMR Spectrum of polymer $\left(\mathrm{P}_{2}\right)$.

4. Metal ions removal studies by the synthesized polymers $\left(P_{1}\right.$ and $\left.P_{2}\right)$

The removal efficiency of the studied heavy metal ions by adsorption on the newly synthesized polymers $\left(\mathrm{P}_{1}\right.$ and $\left.\mathrm{P}_{2}\right)$ was conducted. A comprehensive study of various parameters that influence the adsorption process was carried out, the parameters includes contact time, $\mathrm{pH}$ of the solutions, weight of the polymer, initial metal ion concentration, and finally the temperature of the solution.

\subsection{Effect of contact time}

The effect of contact time between the metal ions of $(\mathrm{Cu}(\mathrm{II}), \mathrm{Cd}(\mathrm{II}), \mathrm{Zn}(\mathrm{II})$, and $\mathrm{Co}(\mathrm{II}))$ and the synthesized two polymers $\left(\mathrm{P}_{1}\right.$ and $\mathrm{P}_{2}$ ) on the removal of these ions was studied using the following intervals $(1,3,5$, 10, 20, 30, and 180) minutes at $25^{\circ} \mathrm{C}$. The concentrations of metal ions at the end of the adsorption process were determined by using atomic absorption spectrometry. The removal efficiency $\mathrm{R} \%$ was calculated by applying equation 1.

$R \%=\frac{(C i-C e)}{C i} \times 100$

Where $C_{i}$ and $C_{e}$ are the initial concentration and the equilibrium concentrations of metal ions, respectively. The optimum contact times of equilibrium of the removal of the studied metal ions on the two polymers were concluded in Table (1).
Table (1)

Contact time at equilibrium between metal ions of $(\mathrm{Cu}(\mathrm{II}), \mathrm{Cd}(\mathrm{II}), \mathrm{Zn}(\mathrm{II})$, and $\mathrm{Co}(\mathrm{II}))$ and the polymers $\left(P_{1}\right.$ and $\left.P_{2}\right)$ at initial concentration, $C_{i}=2 \mathrm{mg} / \mathrm{L}$.

\begin{tabular}{|c|c|c|}
\hline \multirow{2}{*}{ Metal ion } & \multicolumn{2}{|c|}{ Contact time at Ce } \\
\cline { 2 - 3 } & $\mathbf{P}_{\mathbf{1}}$ & $\mathbf{P}_{\mathbf{2}}$ \\
\hline $\mathbf{C u}^{2+}$ & 3 & 20 \\
\hline $\mathbf{C d}^{2+}$ & 1 & 3 \\
\hline $\mathbf{Z n}$ & 1 & 3 \\
\hline $\mathbf{C o}^{2+}$ & 3 & 5 \\
\hline
\end{tabular}

\subsection{Effect of $\mathrm{pH}$}

The $\mathrm{pH}$ of the solutions represents an important parameter could affect the adsorption process. Its value affects the surface charge of the adsorbent, metal ionization and speciation of the metal in the adsorption process. Therefore, the influence of $\mathrm{pH}$ on sorption of metal ions of $(\mathrm{Cu}(\mathrm{II}), \mathrm{Cd}(\mathrm{II})$, $\mathrm{Zn}(\mathrm{II})$, and $\mathrm{Co}(\mathrm{II}))$ on the synthesized polymers $\left(\mathrm{P}_{1}\right.$ and $\left.\mathrm{P}_{2}\right)$ was examined using a range of $\mathrm{pH}(4,6,8,10)$. The same procedure of finding optimum contact time was followed with optimum time for each metal ion with corresponding polymer, Table (1). The adsorption results of the carried experiments are represented in figures (5) and (6). It is clear that the percentage removal of the studied metal ions increases in $\mathrm{pH}$ above 6 . The most expect explanation for these results, is the decrease in the competition between the protons $\left(\mathrm{H}^{+}\right)$available in the solution. The increases in the $\mathrm{pH}$ value of the solution or the 
reduction in proton concentration enhances accessibility of the metal ions to the binding sites of the polymer and furnishing a favorable polymer surface charge for adsorption of the studied metal ions to occur.

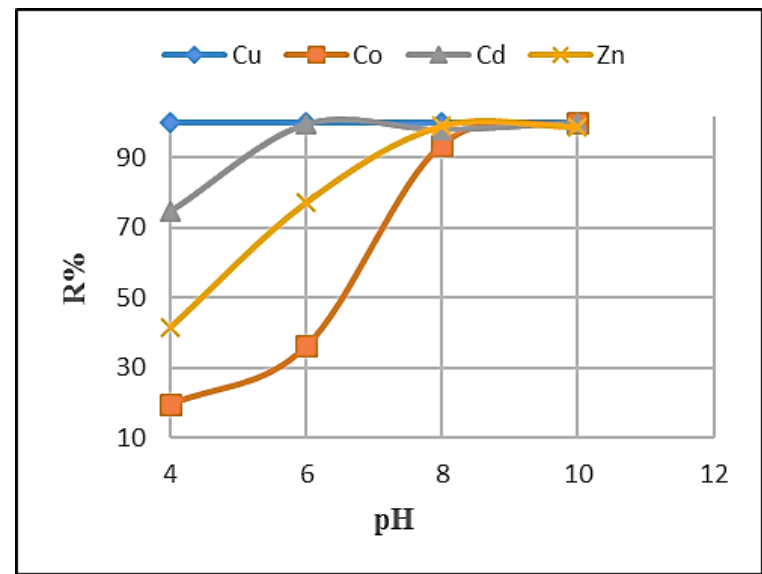

Fig.(5): Effect of the pH of solution on metal ions removal by polymer $P_{1}$.

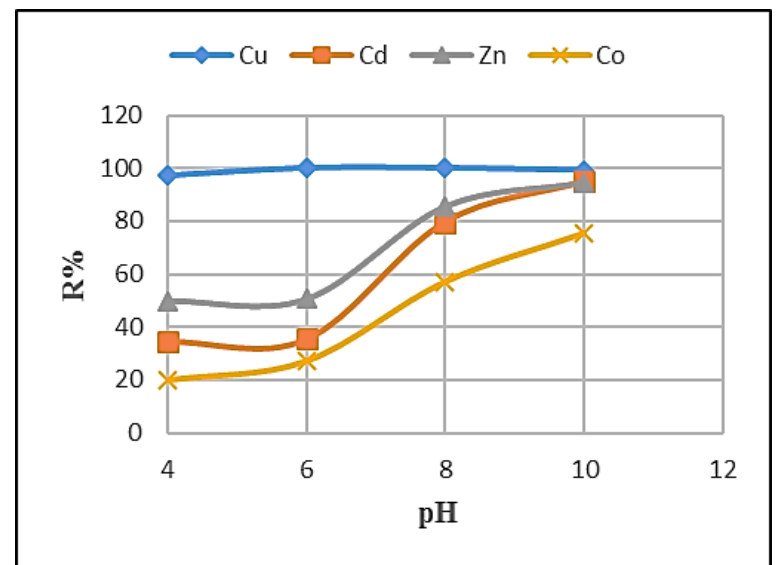

Fig.(6): Effect of the pH of solution on metal ions removal by polymer $P_{2}$.

\subsection{Effect of polymer weight}

The adsorption experiments of metal ions of $(\mathrm{Cu}(\mathrm{II}), \mathrm{Cd}(\mathrm{II}), \mathrm{Zn}(\mathrm{II})$, and $\mathrm{Co}(\mathrm{II}))$ on the two polymers $\left(\mathrm{P}_{1}\right.$ and $\left.\mathrm{P}_{2}\right)$ were repeated to evaluate the role of polymer weight on the adsorption efficiency at $\mathrm{pH} 10$. The results obtained from the adsorption on $0.05 \mathrm{~g}$ polymer $\left(\mathrm{P}_{1}\right)$ revealed that the mentioned polymer is very efficient and caused a total removal of the metal ions under study from the aqueous solutions. Therefore, we did not use polymer weight $\left(\mathrm{P}_{1}\right)$ more than $(0.05 \mathrm{~g})$. Different weights of polymer $\left(\mathrm{P}_{2}\right)$ were used $(0.05,0.06,0.07,0.08,0.09$ and $0.1 \mathrm{~g})$ to study the effect of adsorbent weight on adsorption of studied metal ions. The Fig.(7) shows that increasing the polymer weight has a slight effect on the removal percentage.

\subsection{Effect of initial concentration}

Batch adsorption experiment studies were carried out by stirring of $(0.05 \mathrm{~g})$ of the polymer with $(10 \mathrm{~mL})$ of metal ion solutions of $(\mathrm{Cu}(\mathrm{II}), \mathrm{Cd}(\mathrm{II}), \mathrm{Zn}(\mathrm{II})$, and $\mathrm{Co}(\mathrm{II})$ of different initial concentrations $(2,4,6,8$ and $10 \mathrm{mg} / \mathrm{L})$ at $\mathrm{pH} 10,25^{\circ} \mathrm{C}$ and optimum contact time Table (1). From the Figures (8) and (9), it is observed that the adsorption capacity of the polymeric adsorbents $\left(\mathrm{P}_{1}\right.$ and $\left.\mathrm{P}_{2}\right)$ increases with the increase in the metal ion concentration. The increase may be due to the availability of a high number of adsorbing sites per unit mass of the polymer.

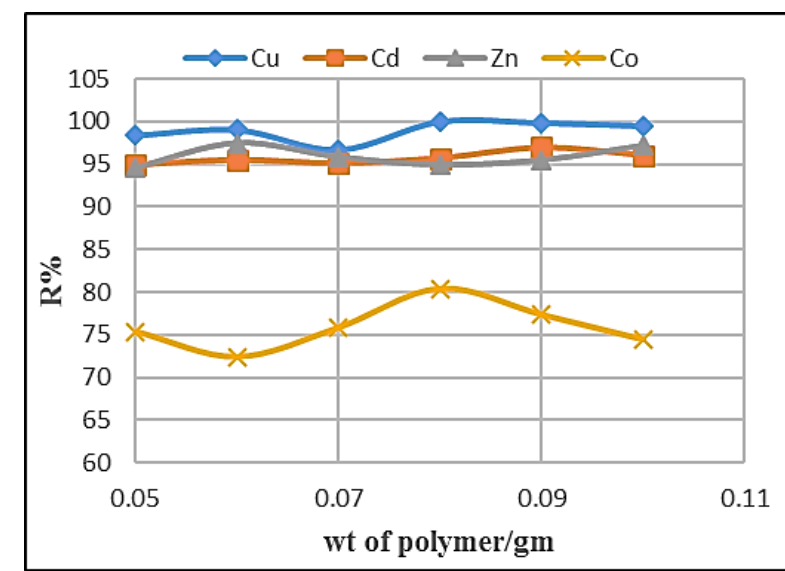

Fig.(7): Effect of polymer weight onto metal ions removal by polymer 2.

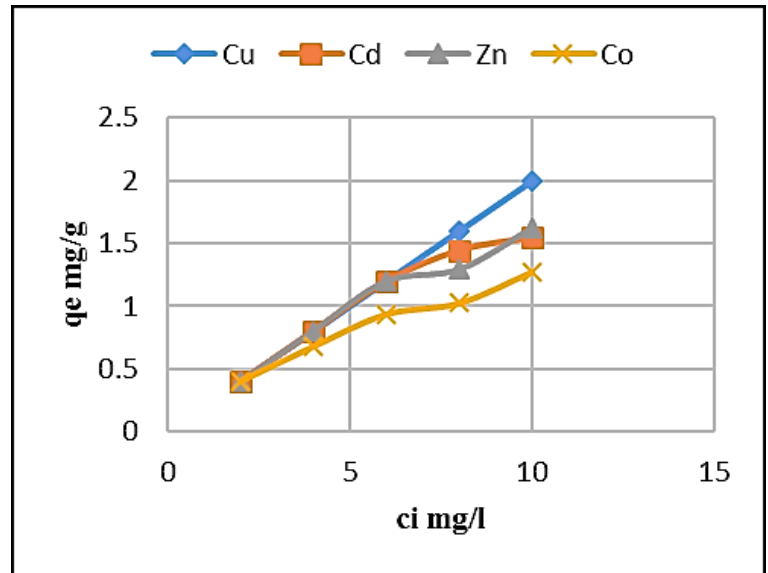

Fig.(8): Effect of initial metal ion concentration on metal ions removal by polymer $\boldsymbol{P}_{1}$. 


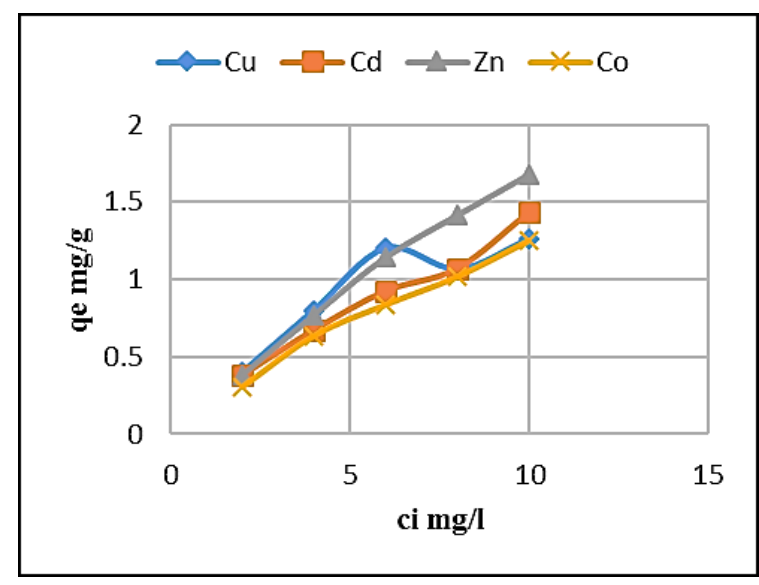

Fig.(9): Effect of initial metal ion concentration on metal ions removal by polymer $\boldsymbol{P}_{2}$.

\subsection{Effect of temperature}

Batch adsorption experiments were performed with adsorbents $\left(\mathrm{P}_{1}\right.$ and $\left.\mathrm{P}_{2}\right)$ at different temperatures $(20,30,40,50$ and $60^{\circ} \mathrm{C}$ ) and the initial concentrations of $(2 \mathrm{mg} / \mathrm{L})$ of the studied metal ions ( $\mathrm{Cu}(\mathrm{II})$, $\mathrm{Cd}(\mathrm{II}), \mathrm{Zn}(\mathrm{II})$, and $\mathrm{Co}(\mathrm{II})$ ) with an adsorbent weight of $(0.05 \mathrm{~g})$ at $\mathrm{pH} 10$.

The effect of temperature on adsorption of the studied metal ions the synthesized polymers $\left(\mathrm{P}_{1}\right.$ and $\left.\mathrm{P}_{2}\right)$ were shown in Figures (10) and (11).

The result indicated that the removal efficiency of the studied polymers did not influence by raising the temperature up to $60^{\circ} \mathrm{C}$. However, a slight improvement was taken place in the case of $\mathrm{Cd}$ and $\mathrm{Co}$ at $60^{\circ} \mathrm{C}$.

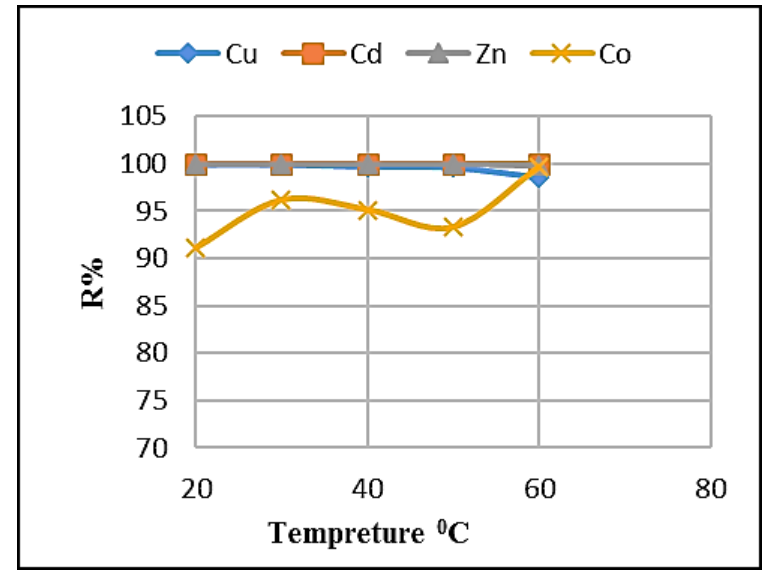

Fig.(10): Effect of the temperature of solution on metal ions removal by polymer $\boldsymbol{P}_{1}$.

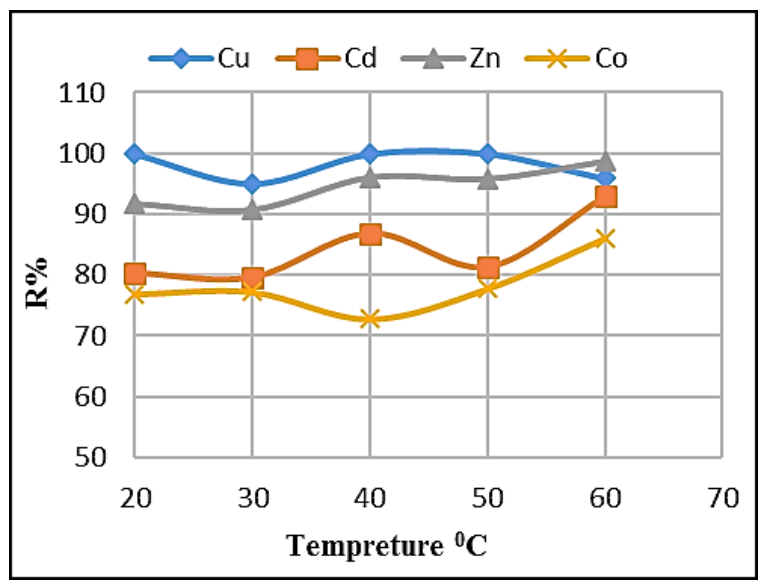

Fig.(11):Effect of the temperature of solution on metal ions removal by polymer $P_{2}$.

\section{Adsorption isotherms}

Adsorption isotherms are described by using various models such as the Langmuir and Freundlich. The adsorption equilibrium results of metal ions $(\mathrm{Cu}, \mathrm{Cd}, \mathrm{Zn}$, and $\mathrm{Co})$ on the synthesized polymers $\mathrm{s}\left(\mathrm{P}_{1}\right.$ and $\left.\mathrm{P}_{2}\right)$ were studied with two isotherm equations.

The Langmuir treatment assumes that the maximum adsorption is related corresponds to a saturated monolayer of solute molecules on the adsorbent surface and the energy of adsorption is not variable, Moreover, there is no migration between the adsorbate species in the plane of the surface. The linear relationship of Langmuir model is illustrated by equation 2:

$\frac{C e}{q e}=\frac{1}{b Q o}+\frac{1}{Q o} \mathrm{C}_{\mathrm{e}}$

$\mathrm{Ce}$ represents the equilibrium concentration of the adsorbate $(\mathrm{mg} / \mathrm{L}), \mathrm{Q}_{0}$ is Langmuir constant linked to adsorption capacity and b is a constant associated with the affinity between the adsorbat and the adsorbent. The values of $\mathrm{Q}_{0}$ and $\mathrm{b}$ could be fined from plotting of $\mathrm{Ce} / \mathrm{qe}$ vs. $\mathrm{Ce}$.

The essential conclusion of the Langmuir model [24] can be described by the dimensionless constant separation factor $\left(\mathrm{R}_{\mathrm{L}}\right)$ calculated from the following equation:

$\mathrm{R}_{\mathrm{L}}=\frac{1}{1+b C o}$

Where $b$ represents the Langmuir constant $\left(\mathrm{L} \mathrm{mg}^{-1}\right.$ ) and $\mathrm{C}_{\mathrm{o}}$ is the initial concentration of the solution $\left(\mathrm{mg} \mathrm{L}^{-1}\right)$. It has been found that for favorable adsorption, $0<\mathrm{R}_{\mathrm{L}}<1$; for unfavorable 
adsorption, $\mathrm{R}_{\mathrm{L}}>1$; for linear adsorption, $\mathrm{R}_{\mathrm{L}}=1$; and finally, when $\mathrm{R}_{\mathrm{L}}=0$, the adsorption Process is irreversible.

The Freundlich isotherm employes to describe heterogenous systems. The presence of different active groups on the surface of the adsorbat in addition to various interactions between adsorbent and adsorbate raises the heterogeneity of the systems. The isotherm results based on the assumption that the sites of adsorption are spread exponentially corresponding to adsorption heat. The second assumption states that the priority to the stronger adsorption sites to be occupied, However, a decrease in the binding strength takes place with increase of occupation of the binding sites. The equation 4 represents the Freundlich model linear form:

$\log Q_{e}=\log K_{F}+(1 / n) \log C_{e}$

$\mathrm{K}_{\mathrm{F}}$ represents Freundlich isotherm constant and related to maximum adsorption capacity and $\mathrm{n}$ is a Vs.process. If $\mathrm{n}=1$, the adsorption is linear; if $\mathrm{n}>1$, adsorption is a physical process; and if $\mathrm{n}<1$, adsorption is a chemical process. From plotting $\log _{e}$ Vs. $\log C_{e}$, the values of $\mathrm{K}_{\mathrm{F}}$ and $\mathrm{n}$ are obtained. While plotting $\mathrm{C}_{\mathrm{e}} / \mathrm{qe} \mathrm{Vs} . \mathrm{C}_{\mathrm{e}}$ at $25^{\circ} \mathrm{C}$ lead to calculate the Langmuir constants, $\mathrm{b}(\mathrm{L} / \mathrm{mg})$ and $\mathrm{q}_{0}(\mathrm{mg} / \mathrm{g})$ and the $\mathrm{R}^{2}$ values (listed in Table 2). The $\mathrm{R}_{\mathrm{L}}$ values for polymers $\left(\mathrm{P}_{1}\right.$ and $\left.\mathrm{P}_{2}\right)$, Table (3) were found to be between $0-1$, indicating the favorable nature of adsorption [25].

Table (2)

Langmuir isotherm constants for the removal of metal ions by polymers $\left(P_{1}\right.$ and $\left.P_{2}\right)$, at $25^{\circ} \mathrm{C}$.

\begin{tabular}{|c||c|c||c||c||c||}
\hline \hline adsorbent & parameters & $\mathbf{C u}^{+2}$ & $\mathbf{C d}^{+2}$ & $\mathbf{Z n}^{+2}$ & $\mathbf{C o}^{+2}$ \\
\hline \hline \multirow{3}{*}{$\mathrm{P}_{1}$} & $\mathrm{q}_{0}$ & 0.791 & 0.791 & 1.502 & 2.103 \\
\cline { 2 - 6 } & $\mathrm{b}$ & 12.63 & 6.479 & 27.96 & 1.621 \\
\cline { 2 - 6 } & $\mathrm{R}^{2}$ & 0.993 & 0.999 & 0.977 & 0.909 \\
\hline \multirow{3}{*}{$\mathrm{P}_{2}$} & $\mathrm{q}_{0}$ & 1.197 & 1.463 & 2.005 & 1.927 \\
\cline { 2 - 6 } & $\mathrm{b}$ & 29.51 & 1.720 & 3.076 & 0.282 \\
\cline { 2 - 6 } & $\mathrm{R}^{2}$ & 0.989 & 0.907 & 0.976 & 0.918 \\
\hline
\end{tabular}

In Freundlich model studies, the values of $1 / \mathrm{n}$ are all less than 1 , which is an indication of favorable sorption. However, a better sorption and relatively stronger bond between adsorbent and adsorbent could be expected at smaller values of $1 / \mathrm{n}$ [26]. The Freundlich constants, $\mathrm{K}_{\mathrm{F}}$ and $\mathrm{n}$ values with the $\mathrm{R}^{2}$ values were estimated from the plot of log qe versus $\log \mathrm{Ce}$ at $25{ }^{\circ} \mathrm{C}$ and are listed in Table (4). The value of $\mathrm{n}$ is between 1.61 and 24 for all experiments which indicates that the adsorption takes place by chemical and physical process [27]. According to the quality of best fit of the isotherms of the studied metal ion adsorption on the synthesized two polymers $\left(\mathrm{P}_{1}\right.$ and $\left.\mathrm{P}_{2}\right)$, the values of $\mathrm{R}^{2}$ showed that Langmuir model is more adequate than Frundich model.

Also the results of $\mathrm{R}^{2}$ based on the experimental data, identified that the adsorption process follows Langmuir model more than Freundich model. It refers also to the homogeneity of the adsorption sites at the surfaces of the polymers with a monolayer coverage of the surface by the studied metal ions. The last conclusion of these results describes the identity of adsorption sites as energically identical.

Table (3)

The $R_{L}$ values for the removal of metal ions by polymers $\left(P_{1}\right.$ and $\left.P_{2}\right)$.

\begin{tabular}{|c|c|c|c|}
\hline \multirow{2}{*}{$\begin{array}{c}\text { Metal } \\
\text { ion } \\
\end{array}$} & \multirow{2}{*}{$\begin{array}{c}\mathrm{Ci} \\
\mathrm{mg} / \mathrm{L}\end{array}$} & \multicolumn{2}{|c|}{$\mathbf{R}_{\mathbf{L}}$} \\
\hline & & $\mathbf{P}_{1}$ & $\mathbf{P}_{2}$ \\
\hline \multirow{5}{*}{$\mathrm{Cu}^{2+}$} & 2 & 0.00039 & 0.0166 \\
\hline & 4 & 0.00019 & 0.0084 \\
\hline & 6 & 0.00031 & 0.0056 \\
\hline & 8 & 0.00098 & 0.0042 \\
\hline & 10 & 0.00079 & 0.0033 \\
\hline \multirow{5}{*}{$\mathrm{Cd}^{2+}$} & 2 & 0.00077 & 0.225 \\
\hline & 4 & 0.00038 & 0.126 \\
\hline & 6 & 0.00025 & 0.088 \\
\hline & 8 & 0.00019 & 0.067 \\
\hline & 10 & 0.00015 & 0.054 \\
\hline \multirow{5}{*}{$\mathbf{Z n}^{2+}$} & 2 & 0.0175 & 0.139 \\
\hline & 4 & 0.0088 & 0.075 \\
\hline & $\overline{6}$ & 0.0059 & 0.051 \\
\hline & 8 & 0.0044 & 0.039 \\
\hline & 10 & 0.0035 & 0.031 \\
\hline \multirow{5}{*}{$\mathrm{Co}^{2+}$} & 2 & 0.23 & 0.683 \\
\hline & 4 & 0.13 & 0.469 \\
\hline & 6 & 0.09 & 0.370 \\
\hline & 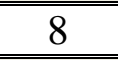 & 0.07 & 0.306 \\
\hline & 10 & 0.05 & 0.261 \\
\hline
\end{tabular}




\subsection{Thermodynamic studies}

Some thermodynamic parameters, such as, Gibbes free energy $\Delta G^{\circ}$, enthalpy change $\Delta \mathrm{H}^{\circ}$, and entropy change $\Delta S^{\circ}$, for the adsorption processes were calculated using the equations (5), (6), and (7) at a temperature range of (293 to $333^{\circ} \mathrm{K}$ );

$$
\ln K d=\frac{\Delta S^{\circ}}{R}-\frac{\Delta H^{\circ}}{R T}
$$

$\mathrm{R}$ is the universal gas constant (8.314 $\mathrm{J} / \mathrm{mol} \mathrm{K}), \mathrm{T}\left(\mathrm{K}^{\mathrm{o}}\right)$ is the absolute temperature of the solution and $K_{d}$ is the distribution coefficient which it is calculated from equation (6).

$$
K d=\frac{C A e}{C e}
$$

Where $\mathrm{C}_{\mathrm{Ae}}(\mathrm{mg} / \mathrm{L})$ is the amount adsorbed on the polymer at equilibrium and $\mathrm{Ce}(\mathrm{mg} / \mathrm{L})$ is the equilibrium concentration. The values of $\Delta \mathrm{H}^{\circ}$ and $\Delta S^{\circ}$ were calculated from the slop and intercept respectively, of the plot between $\ln$ $\mathrm{K}_{\mathrm{d}}$ vs. $1 / \mathrm{T}$. For $\mathrm{P}_{1}$, and $\mathrm{P}_{2}$ polymers, $\Delta G^{\circ}$ was calculated using the relationship below:

$\Delta G=-R T \ln K d$

The thermodynamic parameters are used to evaluate the feasibility and the nature of the adsorption process. The parameters $\left(\Delta S^{\circ}\right)$ and $\left(\Delta H^{\circ}\right)$ have positive values at most cases. Positive $\left(\Delta H^{\circ}\right)$ values refer to the endothermic adsorption process, and the positive values of standard entropy $\left(\Delta S^{\circ}\right)$ showed the affinity of polymers $\left(\mathrm{P}_{1}\right.$ and $\left.\mathrm{P}_{2}\right)$ for metal ions $(\mathrm{Cu}(\mathrm{II})$, $\mathrm{Cd}(\mathrm{II}), \mathrm{Zn}(\mathrm{II})$ and $\mathrm{Co}(\mathrm{II}))$ because of the increased randomness at the interface between the polymer and metal ions solution phases [28]. It is clear from the negative values of $\Delta G^{\circ}$ for the adsorption of all four metal ions onto the used two polymers that the processes are spontaneous nature and feasible [29], Table (5).

Table (4)

Freundlich isotherm constants for the removal of metal ions by polymers $\left(P_{1}\right.$ and $\left.P_{2}\right)$.

\begin{tabular}{|c||c||c||c||c||c|}
\hline adsorbent & parameters & $\mathbf{C u}^{+2}$ & $\mathbf{C d}^{+2}$ & $\mathbf{Z n}^{+2}$ & $\mathbf{C o}^{+2}$ \\
\hline \hline \multirow{3}{*}{$\mathrm{P}_{1}$} & $\mathrm{n}$ & 8.63 & 7.50 & 10.9 & 7.9 \\
\cline { 2 - 6 } & $\mathrm{K}_{\mathrm{F}}$ & 0.50 & 1.50 & 1.23 & 0.90 \\
\cline { 2 - 6 } & $\mathrm{R}^{2}$ & 0.055 & 0.738 & 0.295 & 0.894 \\
\hline \multirow{3}{*}{$\mathrm{P}_{2}$} & $\mathrm{n}$ & 24 & 2.76 & 2.14 & 1.61 \\
\cline { 2 - 6 } & $\mathrm{K}_{\mathrm{F}}$ & 1.00 & 1.15 & 1.51 & 0.55 \\
\cline { 2 - 6 } & $\mathrm{R}^{2}$ & 0.130 & 0.958 & 0.815 & 0.921 \\
\hline
\end{tabular}

Table (5)

\begin{tabular}{|c|c|c|c|c|c|c|c|c|}
\hline \multirow{2}{*}{ Adsorbent } & \multirow{2}{*}{$\begin{array}{c}\text { Metal } \\
\text { ion }\end{array}$} & \multirow{2}{*}{$\begin{array}{c}\Delta H^{\circ} \\
(\mathbf{k J} / \mathbf{m o l})\end{array}$} & \multirow{2}{*}{$\begin{array}{c}\Delta S^{\circ} \\
(\mathbf{J} / \mathbf{m o l} \\
\mathbf{K}) \\
\end{array}$} & \multicolumn{5}{|c|}{$\Delta G^{\circ}(\mathrm{kJ} / \mathrm{mol})$} \\
\hline & & & & 293K & 303K & 313K & 323K & 333K \\
\hline \multirow{4}{*}{$\mathrm{P}_{1}$} & $\mathrm{Cu}^{+2}$ & -1.04 & -2.59 & -18.1 & -18.7 & -14.7 & -14.4 & -11.5 \\
\hline & $\mathrm{Cd}^{+2}$ & 0.012 & 0.934 & -18.1 & -18.7 & -19.3 & -19.9 & -20.5 \\
\hline & $\overline{\mathrm{Zn}^{+2}}$ & 0.161 & 0.40 & -18.1 & -18.7 & -19.3 & -19.9 & -18.7 \\
\hline & $\mathrm{Co}^{+2}$ & 0.680 & 2.58 & -5.54 & $\begin{array}{l}-7.9 \\
\end{array}$ & -7.5 & $\begin{array}{l}-6.9 \\
\end{array}$ & -1.4 \\
\hline \multirow{4}{*}{2} & $\mathrm{Cu}^{+2}$ & $\begin{array}{l}-0.48 \\
\end{array}$ & -0.86 & -18.5 & $\begin{array}{l}-7.4 \\
\end{array}$ & -19.7 & -20.4 & -8.6 \\
\hline & $\mathrm{Cd}^{+2}$ & 0.27 & 1.10 & -3.4 & -3.4 & -4.9 & -3.9 & -7.0 \\
\hline & $\mathrm{Zn}^{+2}$ & 0.52 & 2.06 & -5.8 & -5.7 & -8.2 & -8.3 & -11.7 \\
\hline & $\mathrm{Co}^{+2}$ & 0.14 & 0.61 & -2.9 & -3.0 & -2.5 & -3.3 & -5.0 \\
\hline
\end{tabular}

The thermodynamic parameters values for the removal of metal ions by polymers $\left(P_{1}\right.$ and $\left.P_{2}\right)$. 


\section{Conclusions}

The reaction of adipoyl dichloride with ammonium thiocyanate in a 1:2 mole ratio yielded adipoyl dithiocyanate as intermediate product. This product reacts with 5-amino1,3,4-thiadiazole-2-thione or 2,6Diaminopyridine to yield the new polymers Poly [5-amino-1,3,4-thiadiazol-2-yl (6methanethioamido-6-oxohexanoyl) carbamodithioate $]\left(\mathrm{P}_{1}\right)$ and Poly $\left[\mathrm{N}^{1}-((6-\right.$ aminopyridin-2-yl) carbamothioyl)- $\mathrm{N}^{6}$ thioformyladipamide] $\left(\mathrm{P}_{2}\right)$. The adsorption study revealed that the two polymers have high adsorption capacity toward $\mathrm{Cu}(\mathrm{II}), \mathrm{Cd}(\mathrm{II})$, $\mathrm{Zn}$ (II) and $\mathrm{Co}$ (II) ions. Langmuir and Freundlich isotherm models were applied to fit the experimental adsorption results. These results correlate well with the isotherm equations. The thermodynamic parameters indicate that the adsorption was a spontaneous, feasible, and endothermic process.

\section{References}

[1] Arslan, H., Külcü N., Flörke U., synthesis and characterization of copper(II), nickel(II) and cobalt (II) complexes with novel thiourea derivatives, Transition Met. Chem., 28(7), 816-819, 2003.

[2] Mansuroglu D. S., Arslan H., Flörke U., Külcü N., Synthesis and characterization of nickel and copper complexes with 2,2diphenyl- $N$-(alkyl (aryl) carbamothioyl) acetamide: The crystal structures of $\mathrm{HL}^{1}$ and cis - $\left[\mathrm{Ni}\left(\mathrm{L}^{1}\right)_{2}\right]$, J. Coord. Chem., 61(19), 3134-3146, 2008.

[3] Ozer C. K., Arslan H., Vanderveer D., Binzet G. Synthesis and characterization of $N$-(alky (aryl) carbamothioyl) cyclohexanecarboxamide derivatives and their $\mathrm{Ni}(\mathrm{II})$ and $\mathrm{Cu}(\mathrm{II})$ complexes, J. Coord. Chem., 62(2), 266-276, 2009.

[4] Binzet G., Arslan H., Flörke U., Külcü N., Duran N., Synthesis, characterization and antimicrobial activities of transition metal complexes of $\quad \mathrm{N}, \mathrm{N}$-dialkyl- $\mathrm{N}$-(2Chlorobenzoyl) thiourea derivatives, J. Coord. Chem., 59(12), 1395-1406, 2006.

[5] Ugur D., Arslan H., Külcü N, Synthesis and Characterization of Novel Thiourea Derivatives and Their Nickel and Copper Complexes, Russ. J. Coord. Chem., 32(9), 669-675, 2006.
[6] Arslan H. Florke U. Kulcu N. Emen M.F., Crystal structure and thermal behaviour of copper(II) and zinc(II) complexes with $N$ pyrrolidine- $N$ '-(2-chloro-benzoyl)thiourea., J. Coord. Chem., 59, 223-228, 2006.

[7] Vivas-Reyes R., Espinosa E., Forlgua J., Arguello E., Theoretical study of a series of N-(N-propyl)- $\quad$ N'-(para-R-benzoyl)thioureas with trans[pt(py) 2cl 2] through chemistry reactivity descriptors based on density functional theory, J.Mol. Struct., 862, 92-97, 2008.

[8] Ozer C. K., Arslan H., Derveer D.V., Külcü N., Synthesis and Characterization of $\mathrm{N}$ (Arylcarbamothioyl)-cyclohexanecarboxamide Derivatives, Molecules, 14,655-666, 2009.

[9] Atis M., Karipcin, F., Sariboga B., Tas M., Celik H., Structural and antimicrobial and computational characterization of 1benzoyl-3-(5-chloro-2-hydroxyphenyl thiourea, Spectrochim. Acta A., 98, 290301, 2012.

[10] Bernstein J. Patterns in hydrogen bonding, functionality and graph set analysis in crystals, Angew. Chem. Int. Ed., 34, 1555-1573, 1995.

[11] Emen M., Arslan H., Kulcu N., Florke U., Duran, N., Synthesis, characterization and antimicrobial activities of some metal complexes with N'-(2-chloro-benzoyl) thiourea ligands: the crystal structure of fac[CoL3] and cis-[PdL2., Pol. J. Chem., 79(10), 1615-1626, 2005.

[12] Khairul W.M., Shariff M.S.S.M., Rahamathullah R., Daud A.I., Shamsuddin M., Soh S.K.C., An efficient palladiumthiourea catalysed heck cross-coupling reaction for molecular electronic interest, Makara J. Techno. 21(2), 58-64, 2017.

[13] Stibrany R.T., Bumby J., Knapp S., Potenza J.A., Emge T.J., Schugar H.J., Synthesis, structure, and spectroscopic properties of (nitrito-o-o)[tris[2-(1-methyl) imidazoyl]methoxy.methane]Cu(11)(TIMM) (NO2)2(1), Inorg. Chim. Acta., 243, 33-37, 1996.

[14] March J., Advanced Organic Chemistry, 3rd ed., John Wiley \& Sons, New York, 1985.

[15] Horning E.C., ed., Organic synthesis collective, volume 3, John Wiley \& Sons, New York, 1985. 
[16] Neville R.G., McGee J.J., High yield synthesis of N-mono and N,N-disubstituted ureas and thioureas from silicon pseudohalides, Can. J. Chem., 41(9), 21232129, 1963.

[17] Arslan H. Duran N., Borekci G., Ozer C. K., Akbay C., Antimicrobial activity of some thiourea derivatives and their nickel and copper complexes, Molecules,14(1), 519-527, 2009.

[18] Saeed A., Florke U., Erben M.F., A review on the chemistry, coordination, structure and biological properties of 1(acyl/aroyl)-3-(non-substituted) thiourea with general formula $\mathrm{R} 1(\mathrm{CO}) \mathrm{N}(1) \mathrm{HC}(\mathrm{S})$ N(3)R2R3, J. Sulfur Chem., 35(3), 318-355, 2014.

[19] Zhang Y., Wei T., Gao L., Phase catalyzed synthesis of arene-bis-aroyl thiourea derivatives, Indian J. Chem., 39B, 700-702, 2000.

[20] Mao X. P., Huang J. F., Duan, Z. F., Du Z. Y., Huang Z. S., Ma L., Gu L. Q., Synthesis and characterization of novel multifunctional acylthiourea polymers, Chin. Chem. Lett., 16(5), 609-612, 2005.

[21] sykes P., A guidebook to mechanism in organic chemistry, $6^{\text {th }}$. Ed., Longman, U.K. 2000.

[22] Odian G., Principles of polymerization $4^{\text {th }}$ ed., John Wiley \& Sons, New Jersey, 2004.

[23] Silverstein, R. M., Bassler, G. C., \& Morril, T., Spectroscopic Identification of Organic Compounds, 4th.ed John Wiley \& sons. New York. 1981.

[24] Weber, T. W., Chakravorti, R. K., Pore and solid diffusion models for fixed bed adsorbers, AlchE J., 20(2), 228-238, 1974.

[25] Hall, K. R., Eagleton, L. C., Acrivos, A.,Vermeulen, T., Pore and solid diffusion kinetics in fixed bed adsorption under constant pattern conditions, Ind. Eng. Chem. Fundam., 5(2), 212-223, 1966.

[26] Hosseini, M., Mertens, S. F., Ghorbani, M., Arshadi, M. R., Asymmetrical Schiff bases as inhibitors of mild steel corrosion in sulphuric acid media, Mater. Chem. Phys., 78(3), 800-808, 2003.

[27] El Nemr, A., Pomegranate husk as an adsorbent in the removal of toxic chromium from wastewater, Chem. Ecol., 23(5), 409425, 2007
[28] Yavuz Ö., Altunkaynak, Y., Guzel, F., Removal of copper, nickel, cobalt and manganese from aqueous solution by kaolinite, Water research, 37(4), 948-952, 2003.

[29] Chen Y.-X., Wang G.-Y., Adsorption properties of oxidized carboxymethyl starch and cross-linked carboxymethyl starch for calcium ion. Colloids Surf. A., 289, 75-83, 2006. 